\title{
Detección de anticuerpos contra el virus de la diarrea viral en bovinos de la provincia de Anta, Cusco, Perú
}

\author{
Antibody detection against bovine viral diarrhea virus in cattle of the province of \\ Anta, Cusco, Peru
}

\author{
Edgar Valdez G. ${ }^{1,3}$, Ignasio Pacheco P. ${ }^{1}$, Walter Vergara A. ${ }^{1}$, Juan Pinto L. ${ }^{1}$, \\ Fiorela Fernández B. ${ }^{1}$, Fiorela Guzmán F. ${ }^{1}$, Hermelinda Rivera G. ${ }^{2}$
}

\section{Resumen}

El objetivo del presente estudio fue determinar anticuerpos contra el virus de la diarrea viral (VDVB) en bovinos, según raza y edad, de cinco distritos de la provincia de Anta, Cusco. Se tomaron muestras de suero de bovinos hembras $(n=1135)$ y machos $(n=57)$ de 262 pequeños ganaderos y una comunidad ganadera. Las muestras se analizaron mediante la prueba de ELISA indirecta. El 50.8\% de las hembras y 43.9\% de los machos tuvieron anticuerpos contra el VDVB. Los porcentajes de bovinos hembras seropositivos en los distritos de Ancahuasi, Zurite, Anta, Cachimayo y Huarocondo fueron de 58.6, 45.5, 63.9, 31.5 y $80 \%$, respectivamente. Todos los ganaderos tuvieron al menos un animal seropositivo. Los anticuerpos contra el VDVB fueron más prevalentes en animales mayores a tres años. Los coeficientes $\mathrm{m} / \mathrm{p}$ de las muestras seropositivas variaron entre $<0.2 \mathrm{y}>1$. Se concluye que el VDVB está ampliamente difundido en bovinos de los cinco distritos de la provincia de Anta y las variaciones del coeficiente $\mathrm{m} / \mathrm{p}$ de las muestras indican que la infección por el VDVB es activa en los animales de la zona.

Palabras clave: bovinos; virus; DVB; anticuerpos; pequeños ganaderos

\section{Abstract}

The aim of this study was to determine antibodies against bovine viral diarrhea virus (BVDV) in cattle, according to breed and age, in five districts of Anta province, Cusco. Serum samples were taken from females $(n=1135)$ and males $(n=57)$ from 262 small farmers

\footnotetext{
${ }^{1}$ Laboratorio de Desarrollo y Validación de Pruebas Serológicas y Moleculares para la Investigación y Diagnóstico de Enfermedades Infecciosas, Escuela Profesional de Zootecnia, Facultad de Ciencias Agrarias, Universidad Nacional de San Antonio Abad del Cusco, Cusco, Perú

${ }^{2}$ Laboratorio de Microbiología y Parasitología, Facultad de Medicina Veterinaria, Universidad Nacional Mayor de San Marcos, Lima, Perú

${ }^{3}$ E- mail: evg1205 hotmail.com
}

Recibido: 6 de febrero de 2018

Aceptado para publicación: 18 de julio de 2018 
and one farmer community. The samples were analyzed by indirect ELISA test. Results showed that $50.8 \%$ of the females and $43.9 \%$ of the males had antibodies against the BVDV. The percentages of seropositive female bovines in the districts of Ancahuasi, Zurite, Anta, Cachimayo and Huarocondo were 58.6, 45.5, 63.9,31.5 and 80\%, respectively. All farmers had at least one seropositive animal. Antibodies against BVDV were more prevalent in animals older than three years. The $\mathrm{s} / \mathrm{p}$ coefficients of the seropositive samples varied between $<0.2$ and $>1$. It is concluded that the BVDV is widely spread in cattle of the five districts of the province of Anta and the variations of the $\mathrm{s} / \mathrm{p}$ coefficient of the samples indicate that the infection by the BVDV is active in the animals of the area of study.

Key words: bovine; virus; BVDV; antibodies; small farmers

\section{INTRODUCCIÓN}

La población bovina del país es de 5156000 cabezas, constituida por animales criollos (63.9\%), Brown Swiss (17.6\%), Holstein $(10.3 \%)$ y otras razas en menor porcentaje. Dentro de la población de animales criollos, el $71 \%$ se encuentra en la sierra, en especial en los departamentos de Puno y Cusco, situados en la zona sureste del país (INEI, 2012). El crecimiento poblacional bovino ha sido de $14.7 \%$ si se compara con la población registrada en el censo pecuario de 1994 (INEI, 2012), favorecido, entre otros, por los programas de apoyo regional y el mayor consumo de derivados lácteos en las grandes ciudades (Revista Agraria, 2002).

A pesar del crecimiento poblacional, los animales presentan severos problemas que afectan su desempeño reproductivo, entre estos, los agentes infecciosos (Gröhn y Rajala-Schultz, 2000; Givens y Marley 2008), especialmente bacterias como Brucella abortus, Leptospira sp, parásitos como Neospora caninum, Tritrichomonas sp, el virus de la diarrea viral bovina (DVB) y en menor grado el virus de la rinotraqueítis infecciosa bovina (IBR) (Rivera, 2001; Borel et al., 2014).

El virus de la diarrea viral bovina (VDVB) pertenece al género Pestivirus de la familia Flaviviridae (Neill, 2013). El VDVB posee un fenotipo citopático (CP) y otro no citopático (NCP) con base a su característica en cultivos in vitro, aspecto muy importante en todo programa de control-erradicación. Basado en las diferencias genéticas de las cepas se distinguen los genotipos 1 y 2 , siendo el genotipo 1 el más prevalente y con muchas cepas variantes que surgen por mutaciones con el fin de evadir al sistema inmune del animal (Vilcek et al., 2005; Neill, 2013; Giammarioli et al., 2015). Cepas de ambos fenotipos y genotipos ocasionan la misma enfermedad. Más del 70\% de las cepas del VDVB son NCP presentes en la naturaleza, de las cuales surgen las cepas CP por mecanismos de mutación. La generación de un ternero portador o persistentemente infectado ocurre cuando la vaca se infecta con una cepa NCP entre los 40 y 125 días de la gestación, cuando el feto es aún inmunológicamente inmaduro (Grooms, 2004; Lanyon et al., 2014).

Estudios serológicos del VDVB llevados a cabo en bovinos productores de leche, bovinos criollos, ovinos y camélidos sudamericanos en el Perú, indican que el virus está ampliamente difundido, con prevalencias que varían entre $20 \%$ y más del $50 \%$ (Aguilar et al., 2006; Cabello et al., 2006; Quispe et al., 2008). No existen estudios epidemiológicos que evidencien cómo y cuándo el virus ingresó al ganado criollo de la sierra, pero el transporte de bovinos de la costa a la sierra con 
fines de mejoramiento genético y sin control sanitario, llevado a cabo en décadas pasadas, pudo haber contribuido a la difusión del virus en la ganadería andina del país. Últimamente, se ha tenido el caso de bovinos Holstein, Brown Swiss y criollos criados por más de 1000 pequeños ganaderos en la provincia de Anta, Cusco, que estaban siendo afectados por problemas que mermaban el desempeño reproductivo, limitando su producción, de allí que muchos ganaderos están migrando a otras actividades como la siembra de alcachofas y otros productos agrícolas (MINAGRI, 2015).

El departamento del Cusco tiene varios distritos donde se desarrolla la ganadería bovina para leche, como la provincia de Anta, pero estudios sobre el estado sanitario son escasos con excepción de la brucelosis y tuberculosis a cargo del Servicio Nacional de Sanidad Agraria (SENASA). Es así, que el objetivo del presente estudio fue detectar la presencia de anticuerpos contra el VDVB en hatos criados en forma semiextensiva $y$ extensiva por pequeños ganaderos en cinco distritos de la provincia de Anta, Cusco.

\section{Materiales y Métodos}

\section{Lugar del Estudio}

El estudio fue llevado a cabo en cinco distritos de la Provincia de Anta, ubicados al noreste de la ciudad del Cusco, a una altitud de $3300 \mathrm{msnm}$. La zona presenta un promedio de precipitación fluvial anual de $700 \mathrm{~mm}$ y temperatura promedio de $12{ }^{\circ} \mathrm{C}$.

En la pampa de Anta se cría principalmente ganado bovino, con una población estimada de 32663 Holstein, Brown Swiss y criollos criados en forma extensiva y semiextensiva por 1052 pequeños ganaderos con un promedio de 4-6 hembras por ganadero (MINAGRI, 2015). El 10\% de los ganaderos utilizan pastos cultivados y el $89 \%$ pastos naturales. El tipo de empadre es mon- ta natural $(60 \%)$ e inseminación artificial (40\%), principalmente a cargo de técnicos del Ministerio de Agricultura y Riego. Una actividad frecuente que se lleva a cabo en la pampa de Anta son las ferias ganaderas donde concurren bovinos de diferentes lugares del Cusco, Arequipa, Puno, así como de otros lugares para compra y venta de animales con fines de mejoramiento genético, para recría o para ser beneficiado.

Datos proporcionados por los ganaderos indican que los problemas más frecuentes observados en sus hatos son los de tipo reproductivo y en menor proporción los de tipo diarreico y respiratorio. Aunque los ganaderos no llevan registros, refieren que los abortos, repeticiones de celo, largos periodos entre partos, y nacimientos de terneros prematuros son los más frecuentes.

\section{Tamaño de Muestra}

El tamaño de muestra corresponde a un muestreo no probabilístico. Debido a que los ganaderos poseen entre 4 y 6 animales en promedio, se optó por incluir a todos los bovinos hembras de raza Holstein, Brown Swiss y criollo entre 6 meses y más de 6 años de cada ganadero, a fin de que en un próximo estudio se pueda identificar a los animales portadores del virus. En el caso del distrito de Huarocondo, los bovinos eran de propiedad de la comunidad y la crianza era extensiva, por lo que se solo se consideraron los animales que estuvieron confinados en el tiempo del muestreo. En total se obtuvieron 1135 muestras de bovinos hembras y de 57 toros de 263 ganaderos (Cuadros 1 y 2 ).

\section{Muestras}

Se obtuvieron muestras de sangre de la vena coxígea. Se extrajeron los sueros mediante centrifugación a $800 \mathrm{~g}$ por $10 \mathrm{~min}$ y se almacenaron en viales a $-20^{\circ} \mathrm{C}$ en el laboratorio de Desarrollo y Validación de Pruebas Serológicas y Moleculares para la Investigación y Diagnóstico de Enfermedades Infec- 
Cuadro 1. Localidad, población bovina, razas, número de ganaderos y número de muestras colectadas para la detección de anticuerpos contra el virus de la diarrea viral bovina en cinco distritos de la provincia de Anta, Cusco, 2016

\begin{tabular}{|c|c|c|c|c|c|}
\hline \multirow{2}{*}{ Distrito } & \multirow{2}{*}{$\begin{array}{c}\text { Población } \\
\text { bovina }\end{array}$} & \multirow{2}{*}{ Ganaderos (n) } & \multirow{2}{*}{ Raza } & \multicolumn{2}{|c|}{ Muestras (n) } \\
\hline & & & & Hembras & Machos \\
\hline \multirow[t]{3}{*}{ Ancahuasi } & 2,687 & 135 & Holstein & 91 & 5 \\
\hline & & & Brown Swiss & 145 & 9 \\
\hline & & & Criollo & 134 & 18 \\
\hline \multirow[t]{3}{*}{ Zurite } & 4,668 & 89 & Holstein & 343 & 0 \\
\hline & & & Brown Swiss & 71 & 3 \\
\hline & & & Criollo & 73 & 1 \\
\hline \multirow{3}{*}{ Anta } & 7,121 & 32 & Holstein & 43 & 6 \\
\hline & & & Brown Swiss & 20 & 0 \\
\hline & & & Criollo & 70 & 7 \\
\hline \multirow[t]{3}{*}{ Cachimayo } & 891 & 6 & Holstein & 65 & 2 \\
\hline & & & Brown Swiss & 34 & 3 \\
\hline & & & Criollo & 31 & 3 \\
\hline \multirow[t]{3}{*}{ Huarocondo } & 1,785 & Comunidad & Holstein & 10 & 0 \\
\hline & & & Brown Swiss & 2 & 0 \\
\hline & & & Criollo & 3 & 0 \\
\hline Total & 17,152 & 263 & & 1,135 & 57 \\
\hline
\end{tabular}

Cuadro 2. Número de bovinos muestreados en el distrito de Anta, Cusco para la detección de anticuerpos contra el virus de la diarrea viral bovina, según raza y edad (2016)

\begin{tabular}{lcccccccc}
\hline Raza & \multicolumn{7}{c}{ Edad (en años) } \\
\cline { 2 - 9 } & $>0.5-<1$ & $1-2$ & $2.5-3$ & $3.5-4$ & $4.5-5$ & $5.5-6$ & $>6$ & Total \\
\hline Holstein & 42 & 78 & 67 & 79 & 52 & 52 & 182 & 552 \\
Brown Swiss & 24 & 47 & 49 & 29 & 29 & 42 & 52 & 272 \\
Criollo & 25 & 53 & 48 & 55 & 37 & 32 & 61 & 311 \\
\hline Total & 91 & 178 & 164 & 163 & 118 & 126 & 295 & 1135 \\
\hline
\end{tabular}

ciosas de la Escuela Profesional de Zootecnia, Facultad de Ciencias Agrarias, Universidad Nacional de San Antonio Abad del Cusco.

\section{Detección de Anticuerpos contra VDVB}

Los anticuerpos contra el VDVB fueron detectados mediante un kit de ELISA indirecta (IDEZZ BVDV p80 Ab Test,
IDEXX), siguiendo las instrucciones del fabricante. Una muestra fue considerada positiva a anticuerpos cuando el coeficiente $\mathrm{m} / \mathrm{p}$ (=Densidad óptica [DO] de la muestra problema - DO del control negativo / DO del control positivo - DO del control negativo) fue igual o mayor a 0.3 , sospechoso con valores entre $>0.2 \mathrm{y}<0.3$ y negativo con valores de $<0.2$. 
Cuadro 3. Seropositividad al virus de la diarrea viral bovina (VDVB) en bovinos hembras de cinco distritos de la provincia de Anta, Cusco (2016)

\begin{tabular}{lcc}
\hline Distrito & $\begin{array}{c}\text { Muestras } \\
(\mathrm{n})\end{array}$ & $\begin{array}{c}\text { Seropositivos } \\
(\%)\end{array}$ \\
\hline Ancahuasi & 370 & 58.6 \\
Zurite & 487 & 45.5 \\
Anta & 133 & 63.9 \\
Cachimayo & 130 & 31.5 \\
Huarocondo & 15 & 80.0 \\
\hline Total & 1,135 & 50.8 \\
\hline
\end{tabular}

Cuadro 4. Anticuerpos contra el virus de la diarrea viral (VDVB) en bovinos hembras de cinco distritos de la provincia de Anta, Cusco, según el tipo racial y sexo (2016)

\begin{tabular}{lcccc}
\hline \multirow{2}{*}{ Raza } & \multicolumn{2}{c}{$\begin{array}{c}\text { Muestreados } \\
(\mathrm{n})\end{array}$} & \multicolumn{2}{c}{$\begin{array}{c}\text { Seropositivos } \\
(\%)\end{array}$} \\
\cline { 2 - 5 } & $\mathrm{H}$ & $\mathrm{M}$ & $\mathrm{H}$ & $\mathrm{M}$ \\
\hline Holstein & 552 & 13 & 50.3 & 53.8 \\
B. Swiss & 272 & 15 & 58.0 & 40.0 \\
Criollo & 311 & 29 & 45.3 & 41.4 \\
\hline Total & 1135 & 57 & 50.8 & 43.9 \\
\hline
\end{tabular}

H: Hembra; M: macho

Cuadro 5. Anticuerpos contra el virus de la diarrea viral en bovinos (VDVB) de cinco distritos de la provincia de Anta, Cusco, según la edad (2016)

\begin{tabular}{ccc}
\hline Edad & $\begin{array}{c}\text { Muestras } \\
(\mathrm{n})\end{array}$ & $\begin{array}{c}\text { Seropositivos } \\
\%\end{array}$ \\
\hline $6-11$ meses & 91 & 23.1 \\
$1-2$ años & 178 & 32.0 \\
$2.5-3$ años & 164 & 40.9 \\
$3.5-4$ años & 163 & 52.7 \\
$4.5-5$ años & 118 & 55.9 \\
$5.5-6$ años & 126 & 69.0 \\
$>6$ años & 295 & 65.4 \\
\hline \multicolumn{1}{c}{ Total } & 1135 & 50.8 \\
\hline
\end{tabular}

\section{Resultados}

El 50.8 (577/1135) de los bovinos hembras mayores a seis meses resultaron positivos a anticuerpos contra el VDVB (Cuadro 3 ), sin mayor diferencia entre razas (Cuadro 4). El porcentaje de animales seropositivos según la edad se presenta en el Cuadro 5. En general, las muestras de suero tuvieron un coeficiente $\mathrm{m} / \mathrm{p}$ que varió entre $<0.2$ (negativo) $\mathrm{y}>1$.

En el caso de los machos, 43.9\% (25/57) resultaron con anticuerpos contra VDVB con $\mathrm{m} / \mathrm{p}$ entre $0.4 \mathrm{y}>1$. Toros seropositivos fueron encontrados en los cuatro distritos (Ancahuasi [14/32], Anta [7/13], Zurite [3/ 4], Cachimayo [1/8]).

\section{Discusión}

El alto porcentaje $(50.8 \%)$ de bovinos hembras con anticuerpos contra el VDVB en los cinco distritos de la provincia de Anta, Cusco (Cuadro 3), indican la experiencia de los animales con el VDVB de campo, ya que los ganaderos de la zona no utilizan las vacunas disponibles en el país contra el VDVB. Todos los animales tenían más de seis meses, siendo poco probable la detección de anticuerpos pasivos, los cuales desaparecen entre 6 a 8 meses de edad (Griebel, 2015).

Los 263 ganaderos de los cinco distritos tuvieron en sus hatos al menos un animal seropositivo. La amplia distribución del virus en los animales de los hatos muestreados indica que existen factores que contribuyen directa o indirectamente a la difusión del virus, siendo posiblemente los más importantes la existencia de animales portadores del virus, las ferias ganaderas, los toros reproductores seropositivos, uso común de las pasturas, libre movimiento de animales entre las diferentes comunidades de la zona, y ausencia de bioseguridad, como refiere Lindberg y Houe (2005). Las ferias ganaderas son actividades frecuentes en la sierra del país y en 
la pampa de Anta concurren en cada evento cerca de 800 animales de diversas procedencias y edad, sin control sanitario sobre los agentes infecciosos de impacto en la vida productiva de los animales. Ha sido demostrado que el libre movimiento de los animales representa tres veces más riesgo de difundir el virus en un área o zona con relación a la transmisión por otros medios (Gates et al., 2013).

Una de las características de la DVB es de ser mayormente subclínica, facilitando su rápida difusión en una población de animales susceptibles sin ser notado, ocasionando severas pérdidas económicas por afectar el desempeño reproductivo y productivo de los animales. Cuando el virus es introducido en un hato pequeño de una región o zona, como aquellos de la pampa de Anta, el virus puede infectar al 100\% de los animales susceptibles. Las vacas no preñadas desarrollan anticuerpos en las dos semanas siguientes a la infección, siendo los anticuerpos más importantes los neutralizantes que logran eliminar al virus del organismo (Ståhl et al., 2008). El catabolismo de estos estos anticuerpos es lento y puede durar varios años, incluso toda la vida del animal (Grooms, 2004). En la vaca gestante el virus puede ocasionar infertilidad temporal, muerte y reabsorción embrionaria, abortos, malformaciones congénitas, nacimiento de terneros inmunotolerantes y portadores del virus, dependiendo del periodo de la gestación en el cual la vaca fue infectada y el biotipo de la cepa viral infectante, pero la vaca queda inmunizada por los anticuerpos desarrollados (Grooms, 2004).

El tipo de crianza donde haya cercanía entre los animales del hato o entre animales de hatos vecinos permite que los animales se infecten y queden inmunizados y protegidos de nuevas infecciones, pues el virus desaparece y la enfermedad es autolimitada (Lindberg y Houe, 2005; Ståhl et al., 2008). No obstante, la ausencia de bioseguridad que caracteriza a este tipo de explotaciones ganaderas permite que el virus circule en los animales en riesgo; es decir, en animales que van naciendo. La presencia del virus en los hatos también puede favorecer una incrementada prevalencia de problemas respiratorios y diarreicos en los terneros (Ridpath, 2010; Brodersen, 2014). La buena respuesta inmune que genera el VDVB en el animal contribuye a la eliminación del virus del hato o área, y es un concepto que se está tomando en cuenta para elaborar programas de control de la enfermedad (Brackenbury et al., 2003; Chase, 2013).

Los anticuerpos contra el VDVB fueron detectados en porcentajes similares en hembras y machos de todas las razas (cuadros 3 y 4), evidenciando el continuo desafío de los animales por el VDVB. Si bien no hay evidencia clínica de la enfermedad, aparte de los problemas reproductivos que refieren los ganaderos, una diferenciación arbitraria de los coeficientes $\mathrm{m} / \mathrm{p}$ considerados como bajos $(>0.2$ a $<0.3)$ medianos $(>0-3 \mathrm{a}<0.8)$ y altos $(>1.0)$ indica que la infección es activa en los animales de la zona, posiblemente debido a la continua introducción del virus durante las ferias, la presencia de animales portadores del virus e incluso de toros en estado de viremia.

Los toros juegan un rol importante en la transmisión del virus. En el presente estudio, el $43.9 \%(25 / 57)$ tuvieron anticuerpos contra el VDVB, donde la mayoría (18/25) presentaba un coeficiente $\mathrm{m} / \mathrm{p}$ entre $0.5 \mathrm{y}>1.0$, indicando animales con altos niveles de anticuerpos contra el VDVB.

\section{Conclusiones}

- El virus de la diarrea viral bovina está ampliamente difundido en bovinos hembras y machos en cinco distritos de la provincia de Anta, Cusco.

- Los altos niveles de anticuerpos contra el virus de la diarrea viral bovina detectados en los bovinos de diferentes razas, sexo, edades y distritos de la provincia de Anta indican infecciones activas en los hatos muestreados. 


\section{Literatura Citada}

1. Aguilar R, Benito A, Rivera H. 2006. Seroprevalencia del virus de la diarrea viral bovina en ganado lechero de crianza intensiva del valle de Lima. Rev Inv Vet Perú 17: 148-153. doi: 10.15381/ rivep.v17i2.1530

2. Borel N, Frey CF, Gottstein B, Hilbe M, Pospischil A, Franzoso FD, Waldvogel A. 2014. Laboratory diagnosis of ruminant abortion in Europe. Vet J 200: 218-229. doi: 10.1016/ j.tvj1.2014.03.015

3. Brackenbury LS, Carr BV, Charleston B. 2003. Aspects of the innate and adaptive immune responses to acute infections with BVDV. Vet Microbiol 96: 337-344. doi: 10.1016/j.vetmic.2003.09.004

4. Brodersen BW. 2014. Bovine viral diarrhea virus infections: manifestations of infection and recent advances in understanding pathogenesis and control. Vet Pathol 51: 453-464. doi: 10.1177/ 0300985813520250

5. Cabello K, Quispe R, Rivera H. 2006. Frecuencia de los virus parainfluenza-3, respiratorio sincitial y diarrea viral bovina en un rebaño mixto de una comunidad campesina de Cusco. Rev Inv Vet Perú 17: 167- 172. doi: 10.15381/ rivep.v17i2.1535

6. Chase CC. 2013. The impact of BVDV infection on adaptive immunity. Biologicals 41: 52-60. doi: 10.1016/ j.biologicals.2012.09.009

7. Gates MC, Woolhouse MEJ, Gunn GJ, Humphry RW. 2013. Relative associations of cattle movements, local spread and biosecurity with bovine viral diarrhea virus (BVDV) seropositivity in beef and dairy herds. Prev Vet Med 112: 285-295. doi: 10.16/jprevetmed.2013.-07.017

8. Givens MD, Marley MSD. 2008. Infectious causes of embryonic and fetal mortality. Theriogenology 70:270-285. doi:10.1016/j.theriogenology.2008.04.018
9. Giammarioli M, Ceglie L, Rossi E, Bazzuchi M, Casiari C, Pitrini S, de Mia G 2015. Increased genetic diversity of BVDV-1: recent findings and implications thereof. Virus Genes 50: 147151. doi: 10.1007/s11262-014-1132-2

10. Griebel PJ. 2015. BVDV vaccination in North America: risks versus benefits. Anim Health Res Rev 16: 27-32. doi: 10.1017/S1466252315000080

11. Gröhn YT, Rajala-Schultz PJ. 2000. Epidemiology of reproductive performance in dairy cows. Anim Reprod Sci 2: 605-614. doi: 10.1016/S0378-4320(00)00085-3

12. Grooms DL. 2004. Reproductive consequences of infection with bovine viral diarrhea viral. Vet Clin NAm Food A 20: 5-19. doi: 10.1016/j.cvfa.2003.11.006

13. [INEI] Instituto Nacional de Estadística e Informática (INEI). 2012. IV Censo Nacional Agropecuario 2012. [Internet]. Disponible en: http:// proyectos.inei.gob.pe/web/ Documentos Publicos/ResultadosFinalesIVCENAGRO.pdf

14. Lanyon SR, Hill FI, Reichel MP, Brownlie J. 2014. Bovine viral diarrhea: pathogenesis and diagnosis. Vet J 199: 201-209. doi: 10.1016/j.tvj1.2013.07.024

15. Lindberg A, Houe H. 2005. Characteristics in the epidemiology of bovine viral diarrhea virus (BVDV) of relevance to control. Prev Vet Med 72: 55-73. doi: 10.1016/j.prevetmed.2005.07.018

16. [MINAGRI] Ministerio de Agricultura y Riego 2015. Anuario estadístico de la producción ganadera 2015. [Internet]. Disponible en: http://siea.minagri.gob.pe/ siea/sites/default/files/anuario produccion_agricola_ganadera2015.pdf

17. Neill JD. 2013. Molecular biology of bovine viral diarrhea virus. Biologicals 41 : 2-7. doi: 10.1016/j.biologicals.2012.07.002 
18. Quispe QR, Ccama SA, Rivera GH, Araínga RM. 2008. El virus de la diarrea viral en bovinos criollos de la provincia de Melgar, Puno. Rev Inv Vet Perú 19: 176-182. doi: 10.15381/ rivep.v19i2.1165

19. Revista Agraria. 2002. La sierra: espacio ganadero. $\mathrm{N}^{\circ} 41$. [Internet]. Disponible en: http://www.larevistaagraria.org/sites/default/files/revista/ragra41/arti-01c.htm

20. Ridpath J. 2010. The contribution of infection with bovine viral diarrhea virus to bovine respiratory disease. Vet Clin N Am Food A 26: 335-348. doi: 10.1016/ j.cvfa.2010.04.003
21. Rivera H. 2001. Causas frecuentes de aborto bovino. Rev Inv Vet Perú 12: 117122. doi: 10.15381/rivep.v12i2.1638

22. Ståhl K, Lindberg A, Rivera H, C Ortiz; Moreno-López J. 2008. Self-clearance from BVDV infections - a frequent finding in dairy herds in an endemically infected region in Peru. Prev Vet Med 83: 285-296. doi: 10.1016/j.prevetmed.2007.08.005

23. Vilcek S, Durkovic B, Kolesarova M, Paton D. 2005. Genetic diversity of BVDV: consequences for classification and molecular epidemiology. Prev Vet Med 72: 31-35. doi: 10.1016/j.prevetmed.2005.08.004 